\title{
The Threat of Judicial Mafia in Indonesia in Discrediting the Principle of the Rule of Law
}

\author{
Hamdan Zoelva*
}

\begin{abstract}
Former Chairman of the Constitutional Court, Republic of Indonesia and Permanent Lecturer in the Doctoral Program of Law at As-Syafi'iyah Islamic University, JI. Raya Jatiwaringin No. 12, Jakarta 13077, Indonesia
\end{abstract}

\begin{abstract}
This paper aims to critically analyze law enforcement against the mafia of the court. The purpose is to improve the quality of legal institutions and improve the legal structure dimension. The objective is to obtain the quality of court institution as closely related to the apparatus's quality and integrity and the integrity of the apparatus to be ensured since the recruitment process also maintains the coaching process. Using the socio-legal approach, the analysis was directed to the practice of mafia threats to the principle of independence and the court's impartiality while threatening the existence of the rule of law. The results showed that the mafia of court arises because of the collusion among the elements of the court's stakeholders, the destruction of the stakeholders that led to the emergence of the various mafia of court practices in Indonesia. The main findings of this study are that the court, as the last bastion of justice and law enforcement, is undoubtedly expected to be independent and impartial following the demands of the rule of law. As a practical implication, the court institution cannot be independent and impartial if there is still a network of crimes that undermine the court system. Courts that only give justice to those who are strong and have access will cultivate what is feared by some legal experts that law is only a tool as instrumentalism for those who have access and power. This is where the threat to the principle of the rule of law lies.
\end{abstract}

Keywords: Legal threat, the mafia of court, existence, rule of law, Indonesia.

\section{INTRODUCTION}

The independence of the court is one of the essential principles of the rule of law. In Indonesia, this principle is guaranteed in Article 24 of the 1945 Constitution paragraph (1), which states that judicial power is an independent power to hold a court to enforce law and justice (Dewi et al., 2016). The Supreme Court carried out the implementation of judicial power with four courts under it and the Constitutional Court. It was also exercised by other bodies stipulated in Article 24 paragraph (2) of the 1945 Constitution, for example, the Prosecutor's Office, Corruption Eradication Commission (KPK), advocates, and others. The importance of the guarantee of court independence is there so that the court in deciding a case filed is impartial, not under pressure, and cannot be influenced, but remains for truth and justice. If the court can be influenced and not become independent, it becomes a severe threat to the state and the establishment of a rule of law (Eddyono, 2017). Factors that can do not affect the independence of the court include pressure of power, pressure from the masses, pressure from the political parties, in the form of money, blackmail, or other actions, and the low integrity and professionalism of law enforcement (Greenberg \& DiVall, 2002; Brandenburg, 2008; Kalb, \& Bannon, 2018; Ristyawati \& Saraswati, 2018).

*Address correspondence to this author at the Former Chairman of the Constitutional Court, Republic of Indonesia and Permanent Lecturer in the Doctoral Program of Law at As-Syafi'iyah Islamic University, JI. Raya Jatiwaringin No. 12, Jakarta 13077, Indonesia;

E-mail: hamdanzoelva@yahoo.com
Since leaving the New Order government (19661998), eradicating corruption, including the mafia of court, has not been adequately addressed. The spirit of reform since the end of the New Order has indeed strengthened the enthusiasm of all parties to eradicate corruption (Isra et al., 2017; Wisnaeni \& Herawati, 2020). Various regulations and legislative reforms regarding corruption were born but did not bring adequate results (Davidson, 2007). Much of the new corruption that has been revealed has occurred after the reform era in a more complex form so that it can no longer be called personal corruption. However, it has created a network of structured deviations that form something called structural corruption. At the beginning of the reformation period, at least People's Consultative Assembly (MPR) Decree No. XI/1998 was issued on eradicating corruption, collusion, and nepotism (KKN), Law No. 28 of 1999 concerning the implementation of a Clean and Free of Corruption, Collusion, and Nepotism, Law No. 28 of 1999 concerning Eradication of Criminal Acts Corruption as amended by Law No. 20 of 2001, Law No. 30 of 2002 concerning the Corruption Eradication Commission, Law No. 46 of 2009 concerning the Corruption Court, Presidential Instruction No. 30 of 1998 concerning Eradication of Corruption, Collusion, and Nepotism, Presidential Instruction No. 5 of 2004 concerning the Acceleration of Corruption Eradication, etc.

Meanwhile, the court was highlighted by the public with the disclosure of various practices of legal irregularities in the institution due to the corrupt 
behavior of individual law enforcement officers. Corruption in the law enforcement process takes place in a complex form, can no longer be called personal corruption, but has created a network of structured deviations that form structural corruption or also often called systemic corruption. Systemic corruption is a form of the mafia of a court or legal mafia, namely the existence of a network of individual law enforcers who carry out various irregularities in the law enforcement process collectively, structured, and with various motives. This fact has resulted in a decline in public trust in the court and further threatens the concept of the independence and impartiality of the court. It is difficult for the court to guarantee the upholding of justice through its decisions if the court is filled by law enforcers who can be "bought" and even enter the legal mafia network. This brief article discusses how the practice of this legal mafia threatens the principle of independence and impartiality of the court while threatening the existence of the rule of law, and its importance.

\section{LITERATURE REVIEW}

The term "mafia" initially originated from the special mention of a hierarchical criminal organization on the island of Sicily, Italy, that worked in illegal fields such as gambling, drug trafficking, protection of prostitution, and others in an organized manner with one of the methods of intimidating and bribing law enforcement official (Antinori, 2012; La Spina, 2014). It is commonly referred to as a secret criminal organization operating in the United States and Italy and engaged in illegal activities such as gambling, dealing, protection, and prostitution. The Encyclopedia Britannica (1957) defines 'mafia' as a hierarchically structured society of primarily Italian or Sicilian birth or extraction criminals. The term applies to the traditional criminal organization in Sicily and also to a criminal organization in the United States. The use of this term became widespread and became so common that when all forms of organized crime.

The term "mafia of the court" itself began to be known in the 1970s. This term was made to describe the law enforcement process that can be bought and turned from the Police, Attorney, Court level to Supreme Court. The organized process of law enforcement deviation is then analogous to the term mafia. Therefore, the term mafia of the court is not a legal terminology but rather a terminology is given by the community to patterns of corruption in the court. In the international world, "court corruption" or corruption in Court institutions is often categorized as systemic corruption because it has a systemic impact, which means that a court organization cannot carry out its functions to provide good service and decision-makers (Buscaglia, 1999).

According to Sebastian Pompe (2005), as quoted in a study by the Committee for Investigation and Eradication of Corruption, Collusion, and Nepotism (KP2KKN), the mafia of the court has four forms. The first is personal corruption, namely forms of corruption committed by law enforcement officials personally/individually. The second is institutional corruption, namely the process of handling cases ranging from the police to the courts that are 'incorrect,' not by legal facts, or not following law procedures. The third is structural corruption, which is a form of corruption by law enforcement agencies by using the authority and facilities of the institution; and the fourth is political corruption, namely the mafia of court related to political factors or people who have political positions or public officials (Butt \& Lindsey, 2010).

In-Law No. 28 of 1999 concerning Eradication of Corruption Crime as amended by Act No. 20 of 2001, it describes the definition of criminal acts of corruption, namely the act of enriching oneself or others against the law which can harm state or economic finances country or the act of misusing the authority, opportunity or means available because of the position which can benefit the individual or the others and can harm the country's finances or the country's economy. The understanding of the law on the Eradication of Corruption has included the definition of corruption, which contains the following two elements: First, the misuse of power that exceeds legal fairness by officials or state apparatus; and Second, prioritizing personal or client interests above the public interest by officials or relevant state apparatus (Lubis \& Scott, 1988; Baswir, 2002). If corruption practices as in the above definition are carried out by law enforcement officers in a systemic law enforcement environment with a network. In that case, it will become a network of Mafia of Court.

Concretely, the above practices can be witnessed alone or even felt by the justice seekers themselves, such as individual prosecutors who extort bribery of investigators in terms of negotiating the status of defendants, embezzlement of cases, regulating the contents of court decisions, and illegal levies administration of legal proceedings (Alkostar, 2002). The disclosure of various acts of law enforcers accompanied by social problems that followed, such as 
the arrest of judges, prosecutors, lawyers who accepted bribes, tax mafia, the legal mafia in cases of illegal logging, to members of the community who fell poor due to trying to buy victory from individual law enforcers. It shows that the mafia is no longer limited to personal corruption but has entered institutional corruption and structural corruption, even more at the level of political corruption because it involves policies and legislation (Widodo, 2012). If these systematic, conspirative, collective, and structured deviations occur in the realm of law enforcement, of course, they are closely related to stakeholder elements in law enforcement institutions. These elements are litigants, judges, prosecutors, lawyers, clerks, police, prison officials, and justice seekers. Collusion and evil cooperation between elements stakeholders cause the mafia of the court to arise (Mustofa, 2013). By not denying other law enforcers, in this case, the role of lawyers is often very decisive that connects the elements of the Court stakeholders can be illustrated as shown in Figure 1.

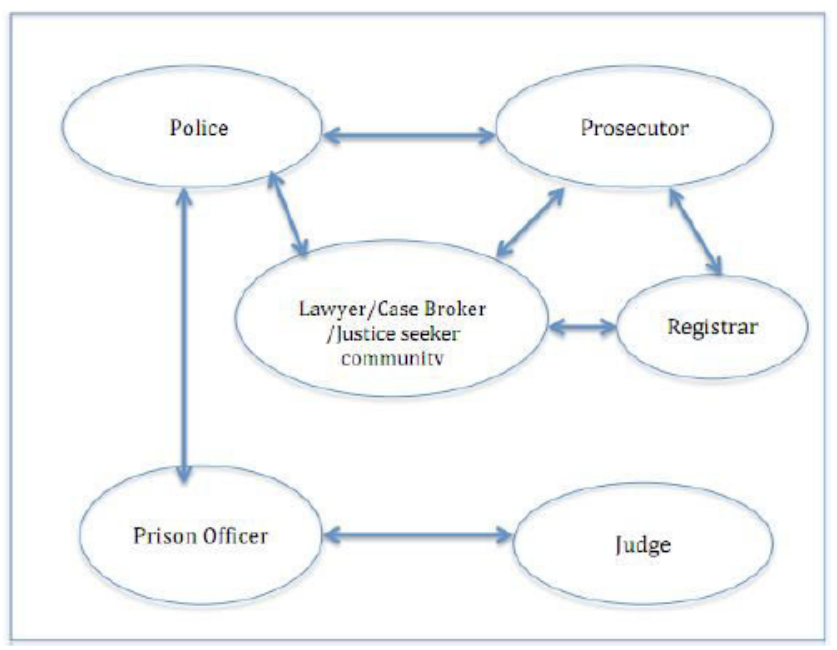

Figure 1: The flow the work of the mafia of court.

Lawyers who sometimes act as case brokers have an essential influence in the formation of organized collusion. Mafia of court cases that occur around bribery of individuals such as judges, prosecutors, police, and prison officers by justice seekers often involve lawyers in them. On the other hand, litigation parties, including lawyers, are forced to get involved in this prohibited network and gross deeds because of pressure and requests from other law enforcement officers, because if not, the case will be defeated. In a position like this, a lawyer is in a difficult position, unless he is a lawyer with high integrity and professionalism. Law enforcers involved in the justice mafia make a double mistake, namely not eradicating corruption and the mafia of the court which is their responsibility, and committing criminal acts of corruption and criminal justice that should have been eradicated. In theory, the crime of the mafia of the court is including the white-collar crime, namely crimes committed by people who are experts and understand the law, who also understand the gaps and shortcomings in existing regulations so that they can escape legal entanglement (Paoli, 2007). Such crimes are a type of crime that is complicated and difficult to disclose except in extraordinary ways, for example, by tapping or providing witness protection to members of a whistle-blower network (La Spina, 2014).

\section{METHOD}

This paper aims to critically analyze law enforcement against the mafia of the court to improve the quality of legal institutions and to improve the legal structure dimension. The method used in this study is by using the socio-legal approach with main emphasis on Friedman's (1975) theory. More specifically, in analyzing the problems of the mafia of court, the used theoretical framework of Friedman (1975) proposes three approaches in understanding the legal system, namely legal structure, legal substance, and legal culture.

The mafia of court can be analyzed in all three dimensions of the legal system. In terms of the substance of legal norms, Indonesia has quite a lot of regulations relating to the eradication and prevention of corruption. Also, in guaranteeing the independence of the court and protecting the court from the legal mafia, the substance of the relevant laws and regulations is quite a lot, including the Criminal Code, Criminal Procedure Code, Court Power Law, Supreme Court Law, Court Law Constitution, Prosecutor's Law, Advocate Law, Court Commission Law and so forth. However, what must be considered is that the substance of the law and norms related to the justice system and law enforcement do not have gaps which can be utilized by the Mafia of Court. In other words, the substance of these norms must support the idea of an integrated court system (Bolifaar et al., 2019). At least in the New Order Period Law No. 3 of 1971 was established on the Eradication of Corruption Crimes, which was then refined in the early reforms through Law No. 28 of 1999 and Law No. 20 of 2001 in addition to the MPR Decree No. XI/1998. regarding eradication of Corruption, Collusion and Nepotism (KKN), Law No. 28 of 1999 concerning the implementation of a Clean and Free of Corruption, Collusion and Nepotism, Law 
No. 30 of 2002 concerning the Corruption Eradication Commission, Presidential Instruction No. 30 of 1998 concerning Eradication of Corruption, Collusion, and Nepotism, Presidential Instruction No. 5 of 2004 concerning the Acceleration of Corruption Eradication and so forth.

\section{RESULTS}

As the influence of the mafia is very complex, this problem must be viewed from the legal structure. Many things must be addressed from legal institutions, especially in terms of quality, both technical knowledge and personal integrity, and supporting factors for the professionalism of the officials involved in these institutions. The problem of the mafia of the court is closely related to the quality and integrity of the court apparatus, ranging from investigators, prosecutors, judges, and lawyers. All law enforcement tools have a wide opportunity for collusion and be involved in the mafia of court network in settling cases. In this case, control and supervision of the principle of the integrity of law enforcement officers are very important. Since the initial screening of law enforcement officials, a rigorous and independent selection process should have been carried out. Reducing corruption, collusion and nepotism practices in the recruitment process can reduce the development of deviant practices that are cultured in court institutions and refresh these institutions with generations with greater integrity. The process of transfer and promotion must also consider this. Buscaglia et al. (1995), examining the corruption of court institutions in Latin American countries, noted that in carrying out internal reform of court institutions, the officials hoped for long-term benefits from the reform process such as increasing career certainty, guaranteeing independence, opportunities to develop career and increasing professional prestige.

In understanding the corrupt behavior of the law enforcement officers, it is not appropriate to increase apparatus welfare to suppress all forms of irregularities, although welfare also affects, because if the apparatus do not have integrity, high benefits will not deter the occurrence of irregularities. Maintaining the integrity of the apparatus is important here, therefore the court should be able to create a monitoring system or mechanism for its officials to maintain this integrity. Transparency or openness in the bureaucratic system and the court system is one way that is believed to be able to narrow the space for the movement of the mafia of court so that collusion between law enforcers, parties, and people seeking justice does not occur. An open and modern court system certainly gives space for the community to understand and then oversee the situation of law enforcement and processes that occur in the Court institution.

Regarding the structural aspects of law enforcement agencies, the establishment of special institutions such as the KPK cannot immediately solve the problems of the mafia of the court as a whole, but it requires good cooperation and consolidation among other law enforcement agencies. The cleaning up of Court institutions and other legal institutions requires a good network of law enforcement officers who are still of high integrity and reformists. It is difficult for the reformist apparatus to improve their institutions if they have to carry out their roles separately from other officials. The court as the last bastion of justice and law enforcement is certainly expected to be independent and impartial following the demands of the rule of law. Court institutions cannot be independent and impartial if there is a network of crimes that damage our justice system. Courts that only provide justice to those who are strong and have access will grow what is feared by Tamahana (2004) that law is only a tool as instrumentalism for those who have access and power. Here is the threat to the principle of the Indonesian rule of law.

From the dimension of legal culture, the condition of the community still provides an opportunity for the development of the mafia of court, for example, there is still a permissive attitude from the litigant parties as well as those involved in seeing Court crimes. Some justice seekers still assume that using corrupt methods such as bribery and so on is still a natural thing to get a victory or escape legal sanctions. Mafia of court in the form of a case broker, will not live if it is not supported by conditions that allow for it in the community. If those who are involved in a case in court together with words and deeds declare "no" for bribery and jointly fight every form of court crime, the mafia will be easier to eradicate. As long as this permissive attitude persists, both intentionally and forcibly, this bad habit will continue. People who already have the habit of paying facilitation payments or bribes in the process the court adds to the difficulty of overcoming the justice mafia Therefore, in court institutions it is important to build a new culture that can diminish this deviant culture, one way is to build the capacity of law enforcement personnel to encourage the emergence of groups of pro-reform law enforcement officers. Young judges, young prosecutors, and lawyers who have idealism and integrity work together and can become professional networks to influence their environment to eradicate the 
practices of the mafia of court. After the formation of this reform group, it is hoped that effective internal checks and balances will be created to build a new culture that enables the establishment of a clean, independent, and impartial court.

To deal with this mafia network, good cooperation is needed between the leaders of law enforcement agencies. Transparency and internal oversight mechanisms in law enforcement agencies are not enough without inter-agency consolidation and coordination. The leaders of the Supreme Court, the Constitutional Court, the Court Commission, the Prosecutor's Office, the Police, the Corruption Eradication Commission, Advocates' organizations, and NGOs and legal observers who represent the community must have a common vision to eradicate these networks and act according to their respective roles. The leaders of law enforcement agencies are expected to be able to open themselves to supervision and investigation to uncover the truth and take firm action against various irregularities that occur within their institutions. It is important for institutions tasked with conducting investigations or investigations such as the Attorney General's Office or the Corruption Eradication Commission to be given adequate access to conduct a thorough investigation of the leaders of the institution. Institutional leaders who tend to be closed to various supervision and investigations from other institutions will result in the mafia elements feeling protected and increasingly free to carry out their actions. The role of NGOs and community organizations is very important in carrying out objective supervision that represents the voice of the general public regarding law enforcement processes that take place in various law enforcement agencies. This was done to improve the deviant legal culture. The role of advocate organizations has also become strong in supervising lawyers with the enforcement of advocate codes of ethics to uphold the integrity and professionalism of advocates.

\section{CONCLUSION}

The results showed that law enforcement against the mafia of the court lies in the quality of the institution, or the legal structure dimension. The quality of this institution is very much related to the quality and integrity of the apparatus in it, the integrity of the apparatus must be ensured since the recruitment process and maintained in the process of guidance. The mafia of court arises because of collusion among the stakeholders of the court. Low integrity and commitment of stakeholders have led to the emergence of the various mafia of court practices in Indonesia.

Theoretically, the results highlight the notion that the mafia of the court was formed because of the legal substance factors that were less supportive and still contained legal gaps that could be exploited by the mafia elements. These norms related to justice and law enforcement must support the creation of an integrated court system so that there are no gaps for the mafia elements to play with the law. The legal culture of justice seekers who tend to be permissive to irregularities and consider this as a natural thing is also one of the factors that make it difficult to overcome this mafia of court. This culture has provided room for broad movement for individuals to develop creating organized deviations.

The results would imply some practical implications, such as maintaining and improving the integrity and commitment of law enforcement officers and improvement of the legal culture of the community. Furthermore, cooperation between law enforcement agencies is needed. These consolidation and collaboration are important to establish and maintain a solid monitoring network and support the emergence of a generation of law enforcement who have high integrity. It is impossible for reforms in law enforcement agencies to be realized only with the actions of one or two officers because corruption and deviations are carried out in a "congregational", collective and conspirative manner and must also be combated collectively.

\section{REFERENCES}

Alkostar, A. (2002). Masalah Mafia Peradilan dan Penanggulangannya. Jurnai Hukum, Fakultas Hukum UII 21 (9), 1-8. https://doi.org/10.20885/iustum.vol9.iss21.art1

Antinori, A. (2012). Organized crime, the mafia, white-collar crime, and corruption. Financial crimes: A threat to global security, 145-160.

https://doi.org/10.1201/b12158-11

Baswir, R. (2002). The dynamics of corruption in Indonesia: in a structural perspective. Jurnal Universitas Paramadina, 2(1), 25-34.

Bolifaar, A.H., Jaya, N.S.P., Pujiyono, \& Arif, F. (2019). Authority of Indonesian attorney in handling the corruption crimes: A perspective of integrated criminal justice system. Journal of Legal, Ethical and Regulatory Issues 22(5), 1-8.

Brandenburg, B. (2008). Courts Under Pressure: The Growing Threat To Impartial Justice. Syracuse L. Rev., 59, 371.

Britannica, I. E. (1957). Encyclopædia britannica. Encyclopaedia Britannica, Incorporated.

Buscaglia, E. (1999). Judicial corruption in developing countries: Its causes and economic consequences. California: Hoover Institution at Stanford University in California 
Buscaglia, E., Dakolias, M., \& Ratliff, W. E. (1995). Judicial reform in Latin America: A framework for national development (No. 65). Hoover Inst Press.

Butt, S., \& Lindsey, T. (2010). Judicial mafia: The courts and state illegality in Indonesia. In The state and illegality in Indonesia (pp. 189-213). Brill. https://doi.org/10.1163/9789004253681_011

Davidson, J. S. (2007). Politics-as-usual on trial: regional anticorruption campaigns in Indonesia. The Pacific Review, 20(1), 75-99. https://doi.org/10.1080/09512740601133237

Dewi, Y. T. N., Tjandra, W. R., \& Niemann, G. R. (2016). Independence of Judicial Power as a Foundation of Human Rights Judicial Function in Indonesia. International Journal of Social Science and Humanity, 6(3), 239-242. https://doi.org/10.7763/IJSSH.2016.V6.650

Eddyono, L. W. (2017). Independence of the Indonesian Constitutional Court in Norms and Practices. Const. Rev., 3, 71. https://doi.org/10.31078/consrev314

Friedman, L. M. (1975). The legal system: A social science perspective. Russell Sage Foundation.

Greenberg, S., \& DiVall, L. A. (2002). Courts under Pressure-A Wake-Up Call from State Judges. Judges J., 41, 11.

Hamilton-Hart, N. (2001). Anti-corruption strategies in Indonesia. Bulletin of Indonesian Economic Studies, 37(1), 65-82. https://doi.org/10.1080/000749101300046519

Isra, S., Amsari, F., \& Tegnan, H. (2017). Obstruction of justice in the effort to eradicate corruption in Indonesia. International Journal of Law, Crime and Justice, 51, 72-83. https://doi.org/10.1016/j.ijlcj.2017.07.001

Kalb, J., \& Bannon, A. (2018). Courts under Pressure: Judicial Independence and Rule of Law in the Trump Era. NYUL Rev. Online, 93, 1.
La Spina, A. (2014). The fight against the Italian mafia. The Oxford handbook of organized crime, 593-611. https://doi.org/10.1093/oxfordhb/9780199730445.013.022

Lubis, M., \& Scott, J. C. (Eds.). (1988). Bunga Rampai Korupsi. LP3ES.

Mustofa, M. (2013). Suap Menyuap dan Mafia Peradilan di Indonesia: Telaah Kriminologis. Masalah-Masalah Hukum, 42(1), 1-5.

Paoli, L. (2007). Mafia and organised crime in Italy: the unacknowledged successes of law enforcement. West European Politics, 30(4), 854-880. https://doi.org/10.1080/01402380701500330

Pompe, S. (2005). The Indonesian Supreme Court: a Study of Institutional Collapse. Cornel: Cornel University. https://doi.org/10.7591/9781501718861

Ristyawati, A., \& Saraswati, R. (2018). An Effort of Political Party Simplification for the Effective Government Realization. IOP Conference Series: Earth and Environmental Science, 175(1), 012170. https://doi.org/10.1088/1755-1315/175/1/012170

Tamahana, B. Z. (2004). On the rule of law: History, politics, theory. Cambridge, UK: Cambridge University Press. https://doi.org/10.1017/CBO9780511812378

Widodo, J. P. (2012). Reformasi Sistem Peradilan Pidana dalam Rangka Penanggulangan Mafia Peradilan. Jurnal Dinamika Hukum, 12(1), 108-120. https://doi.org/10.20884/1.jdh.2012.12.1.200

Wisnaeni, F., \& Herawati, R. (2020). The politics of law of Pancasilabased democracy in Indonesia as the world's third-largest democracy. Academic Journal of Interdisciplinary Studies 9(4), 39-45. https://doi.org/10.36941/ajis-2020-0059

Received on 03-02-2021 Accepted on 02-04-2021 Published on 26-04-2021

\section{https://doi.org/10.6000/1929-4409.2021.10.99}

(C) 2021 Hamdan Zoelva; Licensee Lifescience Global.

This is an open access article licensed under the terms of the Creative Commons Attribution Non-Commercial License (http://creativecommons.org/licenses/by-nc/3.0/) which permits unrestricted, non-commercial use, distribution and reproduction in any medium, provided the work is properly cited. 